\author{
Tomasz Rachwal \\ Zakład Przedsiębiorczości i Gospodarki Przestrzennej \\ Instytut Geografii \\ Akademia Pedagogiczna, Kraków
}

\title{
Ksztaltowanie postaw uczniów na lekcjach podstaw przedsiębiorczości
}

Procesy globalizacji oraz transformacji gospodarki narodowej stawiają przed polskim społeczeństwem szczególne wyzwania edukacyjne, których celem jest wykształcenie konkurencyjnego, kompetentnego i przedsiębiorczego człowieka. Przyjmuje się bowiem, że $\mathrm{w}$ fazie informacyjnej rozwoju cywilizacyjnego o konkurencyjności człowieka i w konsekwencji całej gospodarki w największym stopniu decydować będą zasoby kapitału ludzkiego. Wyzwaniom współczesnej, globalnej gospodarki są w stanie sprostać jedynie osoby i społeczeństwa kierujące coraz większe nakłady na inwestycje w umiejętności i wiedzę człowieka Dlatego konieczne były przekształcenia systemu edukacji w Polsce tak, aby funkcjonował on na miarę potrzeb współczesnego społeczeństwa informacyjnego, jak najlepiej przygotowując uczniów do życia w tym społeczeństwie. W poprzednim systemie edukacji udawało się co prawda w dużym stopniu realizować cele $\mathrm{z}$ zakresu wyposażenia uczniów $\mathrm{w}$ wiedzę z różnych dyscyplin naukowych, jednak system ten nie sprzyjał kształceniu umiejętności przygotowujących uczniów do życia we współczesnym świecie. System ten nie sprzyjał także kształtowaniu postaw uczniów. Jak zauważa szereg pedagogów, m.in. B. Suchodolski (1990), Z. Gawlina (2001) i S. Nalaskowski (1999), wynika to w dużej mierze rozpowszechnienia się - szczególnie od lat. 70. XX wieku - prądu pedagogicznego określanego mianem filozofii antypedagogicznej Wedle tego kierunku nie należy wyznaczać celów wychowania, ale badać przebieg psychicznego rozwoju dziecka, pozwalając mu na swobodny rozwój. Zakłada się bowiem w tej koncepcji, że to co z dziecka wyrośnie, będzie na pewno czymś dobrym, a ustalanie ideału wychowania od zewnątrz należy traktować jako akt przemocy skierowany przeciw dobru wychowanka i jego autonomii (Nalaskowski 1999). Antypedagogika programowo nie formułuje więc celów wychowania. Pogląd ten - jak zauważa Z. Gawlina (2001) - jest jednak bardziej ruchem kontestacyjnym niż teorią naukową i przez pedagogikę tradycyjną jest powszechnie krytykowany.

Obserwowany przez wielu pedagogów kryzys wychowania w ostatnich latach wynika także - zdaniem ks. M. Dziewieckiego (2000, 2002, 2004) - oprócz błędnych lub naiwnych koncepcji wychowania, także z gwałtownych przemian społeczno-gospodarczych, kulturowych i cywilizacyjnych na przełomie XX i XXI wieku. Takie czasy, zdaniem autora, wystawiają wychowawców i wychowanków na trudną próbę, gdyż propagują odrzucenie autorytetów, zasad moralnych i norm obyczajowych.

Należy zgodzić się więc z B. Suchodolskim (1990), że mimo fali krytyki i trudności jakie muszą pokonywać nauczyciele-wychowawcy, nie powinni się oni wyrzekać troski o wychowanie uczniów. Wychowanie bowiem pozostaje jednym z głównych czynników kształtowania ludzi, a więc tym samym budowania przyszłości. Należy podkreślić, że wychowanie zajmuje znaczące miejsce w chrześcijańskiej pedagogice personalistycznej. Punk- 
tem wyjścia w wychowaniu chrześcijańskim jest całościowe i realistyczne spojrzenie na człowieka. Wychowanie wg tej koncepcji zakłada więc dążenie do pełnego rozwoju człowieka, czyli do harmonijnego rozwijania jego właściwości fizycznych, emocjonalnych, moralnych, duchowych i intelektualnych. Oparte jest to na fundamentalnym stwierdzeniu, że być dojrzałym człowiekiem to być kimś świadomym i wolnym. Dlatego w personalistycznej koncepcji wychowania kładzie się nacisk na kształtowanie umiejętności myślenia, świadomego, wolnego wyboru, brania odpowiedzialności za te wybory i ponoszenia ich konsekwencji. (Dziewiecki 2000, 2002, 2004; Galarowicz 1993).

Warto podkreślić, że wbrew obiegowej opinii mówiącej, że uczniowie nie życzą sobie, aby nauczyciele wskazywali jakie mają przyjmować postawy, wielu pedagogów zauważa, że właśnie zdecydowana większość uczniów właśnie takich wskazówek oczekuje. Te oczekiwania uczniów pięknie ujął w słowa papież Jan Paweł II, zwracając się we Włocławku w 1991 r. do katechetów, nauczycieli i uczniów: „Młody człowiek jest wrażliwy na prawdę, sprawiedliwość, piękno, na inne wartości duchowe. Młody człowiek pragnie odnaleźć siebie samego, dlatego szuka, czasem burzliwie szuka, prawdziwych wartości i ceni tych ludzi, którzy ich nauczają i według nich żyją. Któż $\mathrm{z}$ nas nie miał $\mathrm{w}$ życiu i nie wspomina z wdzięcznością takiego człowieka: kapłana, nauczyciela, profesora lub przyjaciela, który umiał odsłonić nam nowy świat wartości i wzbudzić dla niego trwały entuzjazm, czy nawet nadać cały kierunek życiu?” (Jan Paweł II, 1991)

Wychowywanie młodzieży w szkole jest procesem ciągłym, odbywa się więc nie tylko na lekcjach wychowawczych, ale na każdej lekcji tym samym także na lekcjach podstaw przedsiębiorczości. Wydaje się wręcz, że przedmiot ten w sposób wyjątkowy umożliwia nauczycielom kształtowanie postaw uczniów, szczególnie fundamentalnej postawy odpowiedzialności za siebie i innych. Według koncepcji nauczania przedmiotu podstawy przedsiębiorczości Z. Makieły i T. Rachwała (Makieła, Rachwał 2002, 2003, 2005a, 2005b; Rachwał 2004), powinien on przede wszystkim przygotowywać „do życia we współczesnym świecie”. Przygotowanie do życia wymaga zaś oprócz wyposażenia w wiedzę i szereg umiejętności, także ukształtowania postaw czyli - używając słów Jana Pawła II (1991) - „położenia fundamenta pod przyszłość człowieka".

Oczywistym jest, że wychowanie nie powinno być tylko dziełem przypadku, ale procesem świadomie ukierunkowanym ku pewnym celom. Dlatego konieczne wydaje się sformułowanie celów z zakresu kształtowania postaw (tzw. celów wychowawczych) do realizacji na przedmiocie podstawy przedsiębiorczości. Zgodnie $\mathrm{Z}$ koncepcją Z. Makieły i T. Rachwała, nauczanie podstaw przedsiębiorczości powinno przyczynić się przede wszystkim do (Makieła, Rachwał 2003):

- rozumienia sensu kształtowania w sobie postawy „przedsiębiorczości” i ciągłego „inwestowania w siebie";

- przyjmowania odpowiedzialności za siebie, ale także za innych (w tym przede wszystkim własną rodzinę, współpracowników, pracowników itd.) i kształtowania umiejętności godzenia własnego dobra $\mathrm{z}$ dobrem innych;

- przyjmowania pozytywnych postaw wobec ludzi;

- kształtowania postaw dialogu i umiejętności słuchania innych;

- umiejętności rozpoznawania wartości moralnych i dokonywania ich hierarchizacji;

- rozumienia roli etyki w życiu społeczno-gospodarczym i postępowania etycznego.

Generalny cel wychowawczy w ramach tego przedmiotu można więc określić w nawiązaniu do słusznie zaproponowanej nazwy przedmiotu - jako „kształtowanie postawy przedsiębiorczej”. Powstaje tu jednak pytanie, co to znaczy „,postawa przedsiębiorcza” i jakie elementy składają się tę postawę? Jest to problem istotny, bo bardzo często pojęcie „,przedsiębiorczość” bywa utożsamiane z zachowaniem i cechami osobowości „przedsiębiorcy”, czyli osoby prowadzącej działalność gospodarczą. Wydaje się, że - szczególnie ze względu na potrzeby edukacji szkolnej - zawężanie „postawy przedsiębiorczej” do zdolności do zało- 
żenia i prowadzenia własnej firmy jest niewłaściwe. Trudno przecież założyć, że każdy absolwent szkoły ponadgimnazjalnej będzie prowadził własną działalność gospodarczą. Dlatego wydaje się, że konieczne jest nieco szersze spojrzenie na „postawę przedsiębiorczości”, która obejmuje przede wszystkim: energię, wytrwałość, zapał do pracy, inicjatywę, kreatywność, ciekawość świata, pewność siebie i wiarę we własne siły, samodyscyplinę, skłonność do wyważonego ryzyka i brania odpowiedzialności za siebie i innych Cechy te pozwalają nie tylko na dobre prowadzenie przedsiębiorstwa, tj. bycie przedsiębiorcą, ale pozwalają także na aktywne uczestniczenie w życiu społeczno-gospodarczym (w tym udanym życiu rodzinnym), dające dużo satysfakcji i zadowolenia, niezależnie od charakteru wykonywanej pracy i zajmowanego stanowiska. Człowiek przedsiębiorczy nie boi się trudności, podejmowania nowych, nieznanych zadań, nie załamuje się niepowodzeniami, jest chętny do zdobywania wiedzy i nowych umiejętności, potrafi cieszyć się z sukcesów, jest otwarty na otoczenie, ma zdolność do empatii, potrafi dobrze ułożyć sobie stosunki z innymi ludźmi, panować nad swoimi emocjami oraz postępować zgodnie z wartościami etycznymi. Taki punkt widzenia postawy przedsiębiorczej jest powszechnie przyjmowany przez wielu autorów. Warto tu przytoczyć słowa D. Golemana (1999, s. 434): „Skoro zmienia się gospodarka, zmieniają się również cechy potrzebne do przetrwania w niej, nie mówiąc już od odnoszeniu sukcesów. (...) Nacisk ze strony konkurencji każe docenić ludzi, którzy potrafią się sami motywować do działania, wykazują inicjatywę, odczuwają wewnętrzną potrzebę prześcignięcia samych siebie i mają tyle optymizmu, że nie zniechęcają się niepowodzeniami i porażkami, lecz uporczywie kroczą naprzód." Człowiek przyjmujący postawę przedsiębiorczą, o wysokiej „,inteligencji emocjonalnej” jest więc według D. Golemana $(1999,1997)$ bezcennym skarbem dla każdej firmy. Podobny pogląd ma S. Covey (2003, 2004), współwłaściciel największej na świecie firmy szkoleniowej FranklinCovey Co., szkolącej ponad 75\% przedsiębiorstw z listy 500 największych korporacji Ameryki i 90\% przedsiębiorstw tworzących listę 100 największych korporacji w Stanach Zjednoczonych. Co więcej, uważa on, że nie tylko przyjmowanie tak rozumianej postawy przedsiębiorczej, ale kierowanie się w życiu podstawowymi zasadami, takimi jak sprawiedliwość, szczerość, uczciwość, uznanie godności ludzkiej, służenie innym, cierpliwość, wiara w innych ludzi są warunkiem szczęścia w życiu osobistym i sukcesu w życiu zawodowym. Lektura prac S. Covey’a prowadzi więc do wniosku, że człowiek bez odpowiednio ukształtowanej postawy, nie kierujący się w swoim życiu stałymi zasadami, nie może być dobrym przedsiębiorcą czy menedżerem, niezależnie od wielkości firmy, którą posiada, czy w której pracuje.

Należy podkreślić, że kształtowanie postawy przedsiębiorczości uznano za kluczowe w założeniach programowych przedmiotu podstawy przedsiębiorczości. W podstawie programowej kształcenia ogólnego w ramach tego przedmiotu za najważniejsze cele edukacyjne uznano właśnie ,przygotowanie do aktywnego i świadomego uczestnictwa w życiu gospodarczym” oraz „kształcenie postawy rzetelnej pracy i przedsiębiorczości” (Podstawa programowa... 2002). Na pierwszym miejscu wśród przyjętych zadań szkoły jest „zapewnienie uczniom możliwości uzyskania wiedzy, umiejętności i kształtowania postaw przedsiębiorczych, warunkujących aktywne uczestnictwo w życiu gospodarczym", natomiast realizacja treści nauczania powinna być rozpoczęta właśnie od kształcenia „postawy przedsiębiorczości” oraz umiejętności rozpoznania „mocnych i słabych stron własnej osobowości”, rozwijania „samoakceptacji, asertywności, inicjatywności i odpowiedzialności”.

Oprócz postawienia przestawionych wyżej ogólnych celów w zakresie kształtowania postaw, możliwe i zasadne wydaje się postawienie szczegółowych celów wychowawczych dopasowanych do poszczególnych treści nauczania. W opracowanej przez Z. Makiełę i T. Rachwała (Makieła, Rachwał 2002, 2003, 2005a, 2005b; Rachwał 2004) koncepcji nauczania tego przedmiotu, treści nauczania podzielono na 7 części:

Część I - Istota funkcjonowania gospodarki;

Cześć II - Komunikacja interpersonalna;

Cześć III - Praca; 
Cześć IV - Przedsiębiorstwo;

Część V - Pieniądz i bankowość;

Część VI - Podatki i ubezpieczenia;

Część VII - Współpraca międzynarodowa.

W koncepcji tej podjęto próbę postawienia - oprócz celów z zakresu wyposażenia w wiedzę i kształtowania umiejętności uczniów - szczegółowych celów wychowawczych do każdej z wymienionych części. Proponuje się następujące cele w zakresie kształtowania postaw uczniów:

\section{Część I. Istota funkcjonowania gospodarki}

Uczeń:

- rozumie sens kształtowania w sobie postawy przedsiębiorczości,

- dostrzega zalety życia w systemie gospodarki rynkowej, opartego na własności jako jej głównego filaru;

- potrafi dostrzec i zrozumieć problemy ludzi żyjących w państwach o bardzo niskim PKB, w tym także w państwach, których gospodarka oparta jest na ideologiach komunistycznych i socjalistycznych,

- rozumiejąc zasady funkcjonowania budżetu domowego, rezygnuje z roszczeń finansowych wobec rodziny,

- przyjmuje postawę szacunku dla rodziców (opiekunów), których praca jest źródłem dochodów rodziny,

- $\quad$ wykazuje chęć uczciwego zarabiania pieniędzy (w sposób niekolidujący z nauką) na swoje wydatki lub/i w celu odciążenia budżetu domowego,

- przyjmuje postawę szacunku wiedzy w stosunku do osób odpowiadających za finanse państwa i samorządów (przy zachowaniu krytycyzmu),

- rozumie misję sprawowania funkcji publicznej, w tym dbania o finanse publiczne,

- potępia postawę prywaty urzędników,

- rozumie konieczność zrównoważenia budżetu (państwa, samorządowego i domowego).

\section{Część II. Komunikacja interpersonalna}

Uczeń:

- ma motywację do ciągłego doskonalenia własnej osobowości,

- reaguje na potrzeby innych, zarazem pamiętając o własnych sprawach,

- jest otwarty na otoczenie,

- potrafi pracować w zespole,

- jako lider zespołu potrafi kierować ludźmi sprawiedliwie i profesjonalnie,

- w negocjacjach przyjmuje postawę szacunku wobec drugiej strony,

- w każdej konfliktowej sytuacji dąży do jej rozwiązania,

- rozumie, że wolność jest podstawowym prawem człowieka,

- szanuje cudzą własność,

- jest odpowiedzialny za siebie i innych,

- nie manipuluje ludźmi,

- przyjmuje postawę szacunku wobec prawa (przy zachowaniu krytycyzmu),

- $\quad$ sprzeciwia się wszelkim przejawom korupcji;

- postępuje etycznie ${ }^{1}$.

\section{Cześć III. Praca}

Uczeń:

- uznaje pracę za wartość, a nie tylko źródło dochodów,

- rozumie sens pracy, przyjmuje aktywną postawę w jej poszukiwaniu,

- rozumie konieczność ciągłego „inwestowania w siebie”,

\footnotetext{
${ }^{1} \mathrm{Cel}$ ten - sformułowany ogólniej w stosuniku do pozostałych - jest jednym z najważniejszych, powinien wynikać z całego procesu wychowania w szkole i w domu.
} 
- jest wrażliwy na kwestię bezrobocia i przyjmuje postawę życzliwości wobec osób pozostających bez pracy,

- jako potencjalny pracodawca rozumie potrzebę profesjonalnego i życzliwego traktowania kandydatów do pracy,

- $\quad$ wykazuje chęć należytego wypełniania obowiązków pracownika lub pracodawcy,

- potępia postawę unikania pracy,

- potrafi po dżentelmeńsku rozwiązać umowę o pracę,

- $\quad$ sprzeciwia się wszelkim przejawom dyskryminowania w pracy, mobbingu itp.

- rozumie potrzebę sprawiedliwego wynagradzania pracowników

- rozumie, że wysokość pensji nie powinna być jedynym kryterium wyboru pracy,

- rozumie trudności w zatrudnianiu osób niepełnosprawnych, życzliwie do nich nastawiony i gotowy do przygotowania (w miarę możliwości) w swojej przyszłej firmie miejsce pracy dla osoby niepełnosprawnej.

\section{Cześć III. Przedsiębiorstwo}

Uczeń:

- rozumie, że chociaż zysk jest podstawowym celem działalności gospodarczej, jego osiąganie powinno odbywać się zgodnie z normami prawnymi i moralnymi;

- rozumie specyficzne miejsce kapitału ludzkiego (pracy) i przedsiębiorczości (wyróżnianej często jako 4 czynnik) wśród czynników wytwórczych;

- jest gotowy do podjęcia ryzyka założenia własnej firmy;

- rozumie, że pewne działania marketingowe (np. reklama alkoholu skierowana do młodzieży) są nieetyczne (nawet jeśli w danym kraju są zgodne z prawem),

- rozumie, że obsługa klienta nie polega na sprzedaży towaru lub usługi za wszelką cenę, aby tylko osiągnąć zysk,

- rozumie, że planując własną działalność gospodarczą, nie należy kopiować cudzych pomysłów (np. nazwy lub logo firmy),

- rozumie znaczenie uczciwego, zgodnego z prawem i profesjonalnego zarządzania personelem,

- zamierza z szacunkiem odnosić się zarówno do przełożonych, jak i podwładnych,

- rozumie konieczność rzetelnego prowadzenia księgowości.

\section{Część V. Pieniądz i bankowość}

Uczeń:

- ma szacunek dla pieniędzy, które są efektem uczciwej pracy,

- potępia wszelkie próby podrabiania i wprowadzania do obiegu fałszywych pieniędzy oraz utrzymywania kradzionych czeków i kart płatniczych,

- rozumie konieczność zgłaszania takich przypadków policji,

- znalezioną kart płatniczą, czek lub inne dokumenty zwraca natychmiast właścicielowi i nie próbuje z nich korzystać;

- potępia wszelkie formy kredytowania opartego na lichwie (pobieraniu wygórowanych odsetek dzięki wykorzystaniu niewiedzy lub trudnej sytuacji kredytobiorcy);

- zamierza uczciwie i rzetelnie rozliczać się z innymi osobami, firmami, bankami itd.

\section{Część VI. Podatki i ubezpieczenia}

Uczeń:

- przyjmuje postawę uczciwego podatnika, terminowo składającego deklaracje podatkowe i rzetelnie płacącego podatki,

- dostrzega znaczenie uczestniczenia w systemie ubezpieczeń społecznych, gwarantującym bezpieczeństwo socjalne,

- rozumie konieczność objęcia ubezpieczeniem społecznym i zdrowotnym osób bez pracy (tym samym niepłacących składek),

- dostrzega znaczenie ubezpieczeń majątkowych i osobowych firmy oraz rodziny,

- potrafi rzeczowo i bez skrępowania rozmawiać z bliskimi o polisach na życie;

- potępia wszelkie sposoby wyłudzania odszkodowań od towarzystw ubezpieczeniowych. 


\section{Część VII. Wspólpraca międzynarodowa}

Uczeń:

- określa swoją rolę w otoczeniu lokalnym, regionalnym, krajowym, europejskim i międzynarodowym,

- dostrzega potrzebę współpracy międzynarodowej na wszelkich płaszczyznach, w tym współpracy przygranicznej w ramach układów lokalnych;

- jest gotów pracować dla pomyślnego rozwoju Polski i struktur integracyjnych, w których Polska uczestniczy.

- rozumie potrzebę wyrównywania dysproporcji w poziomie rozwoju społecznogospodarczego państw świata.

Przedstawione powyżej cele wychowawcze należy traktować jako propozycję, z pełną świadomością, że niektóre $\mathrm{z}$ nich mogą być trudne zarówno do zrealizowania, jak i do sprawdzenia. Powinny one być zatem wyzwaniem do podjęcia trudu wychowawczego przez nauczycieli podstaw przedsiębiorczości.

Warto zauważyć na zakończenie, że wychowanie człowieka słusznie bywa nazywane sztuką, gdyż rzeczywiście wymaga geniuszu pedagogicznego. W tak rozumianym procesie wychowania decydującą rolę odgrywają nie programy czy podręczniki, ale oczywiście osoby, czyli nauczyciele. Wymaga to odpowiedniego, podmiotowego podejścia do uczniów i szeregu umiejętności, do których za M. Łabockim (2000) należy zaliczyć przede wszystkim:

- umiejętność akceptowania uczniów zgodnie z założeniami personalizmu,

- umiejętność rozumienia empatycznego,

- umiejętność bycia autentycznym, tzn. otwartym, szczerym i „prawdziwym” w swoim zachowaniu,

- umiejętność skutecznej komunikacji interpersonalnej, w tym pokonywania barier, do których w przypadku nauczycieli należą najczęściej: nakazywanie, grożenie, moralizowanie, ,głoszenie kazań”, pouczanie, krytykowanie, obwinianie, nagminne doradzanie lub sugerowanie gotowych rozwiązań.

Kształtowanie postaw uczniów jest w dzisiejszych czasach wielkim „wyzwaniem” dla nauczycieli, gdyż nie jest to zadanie łatwe. Należy jednak zgodzić się z M. Dziewieckim (2004), że nauczyciel-wychowawca nie powinien poddawać się „wypaleniu” zawodowemu i rezygnować $z$ realizacji celów wychowawczych nawet wtedy, gdy jego oddziaływania wychowawcze zdają się pozostawać bezowocne lub gdy spotykają się z jawnym odrzuceniem czy wręcz szyderstwem ze strony uczniów. Powinien on mieć świadomość, że jest odpowiedzialny za swoją postawę wobec wychowanka, ale nie za jego odpowiedź lub za brak odpowiedzi. Trud poświęcony w kształtowanie postaw nie zawsze będzie owocny. Jednak gdy uczeń widzi, że jego los naprawdę leży na sercu wychowawcy, będzie skłonny skorzystać z jego pedagogicznych oddziaływań. I to będzie korzystał także wtedy, gdy wychowawca będzie mu stawiał - nieuniknione przecież w realistycznej pedagogice - wymagania, normy i ideały. (Dziewiecki 2004). Nagrodą za włożony trud będzie wdzięczność uczniów, najczęściej milcząca, a czasem wypowiedziana publicznie, jak w przypadku nauczycieli najbardziej znanego, nieżyjącego już Polaka, który w cytowanym przemówieniu we Włocławku na koniec powiedział: „Powinienem na tym zakończyć, ale nie mogę. Nie mogę, bo uświadomiłem sobie co ja zawdzięczam polskiej szkole. Dlatego pragnę dzisiaj tu, z tego miejsca i przy okazji tego spotkania, po prostu ucałować jeszcze raz ręce moim rodzicom, a równocześnie ucałować ręce wszystkim moim nauczycielom, nauczycielkom i moim katechetom, którzy uczyli mnie w szkole podstawowej, w gimnazjum, aż do matury, kładąc fundamenta pod przyszłość człowieka" (Jan Paweł II, 1991). Trudno chyba o bardziej wzruszające podziękowanie dla nauczycieli za trud wychowawczy, tym bardziej, że padły one $z$ ust człowieka, który sprawował jeden z najwyższych urzędów na świecie, a także był i nadal jest niekwestionowanym autorytetem moralnym dla niemal całej ludzkości, w tym także dla niewierzących. 


\section{LITERATURA}

Bachta A. i in., 2003, Podstawy przedsiębiorczości. Scenariusze zajęć edukacyjnych dla liceum ogólnoksztatcacego, liceum profilowanego i technikum, praca zbiorowa, Wydawnictwo Nowa Era. Warszawa.

Covey S. R., 2003, Siedem nawyków skutecznego działania, wyd. III popr., Rebis, Poznań.

Covey S. R., 2004, Zasady skutecznego przywództwa, wyd. II popr., Rebis, Poznań.

Dziewiecki M., 2000, Cele i metody wychowania chrześcijańskiego, Referat wygłoszony 29.IV.2000 r. w Rzeszowie w ramach sympozjum na temat wychowania (za www.opoka.org.pl).

Dziewiecki M., 2002, Wychowanie w dobie ponowoczesności, „Jedność”, Kielce.

Dziewiecki M., 2004, Pedagog na trzecie tysiaclecie, [w:] Czytelnia „Opoki” (www.opoka.org.pl).

Galarowicz J., 1993, 'Powołani do odpowiedzialności, Oficyna Naukowa i Literacka T. I. C., Kraków.

Gawlina Z., 2001, Ksztaltowanie postawy czynnej ważnym celem wychowania,[w:] Kształtowanie postaw czynnych i więzi środowiskowych, red. Z. Gawlina, Wydawnictwo Uniwersytetu Jagiellońskiego, Kraków.

Goleman D., 1997, Inteligencja emocjonalna w praktyce, Media Rodzina, Poznań.

Goleman D., 1997, Inteligencja emocjonalna, Media Rodzina, Poznań.

Jan Paweł II, 1991, Przemówienie do katechetów, nauczycieli i uczniów, Włocławek, 6 czerwca $1991 \mathrm{r}$.

Makieła Z., Rachwał T., 2002, Podstawy przedsiębiorczości. Program nauczania dla liceum ogólnoksztatcacego, liceum profilowanego i technikum, Wydawnictwo Nowa Era. Warszawa.

Makieła Z., Rachwał T., 2003, Podstawy przedsiębiorczości. Poradnik metodyczny dla nauczycieli liceum ogólnokształcacego, liceum profilowanego i technikum. (wydanie drugie zm.), Wydawnictwo Nowa Era. Warszawa.

Makieła Z., Rachwał T., 2005a, Podstawy przedsiębiorczości. Podręcznik dla liceum ogólnoksztatcacego, liceum profilowanego i technikum (wydanie czwarte zm.), Wydawnictwo Nowa Era. Warszawa.

Makieła Z., Rachwał T., 2005b, Podstawy przedsiębiorczości. Zeszyt ćwiczeń dla liceum ogólnoksztatcacego, liceum profilowanego i technikum. (wydanie czwarte zm.), Wydawnictwo Nowa Era. Warszawa.

Nalaskowski S., 1999, O ideale wychowania i celach kształcenia, Wyd. Adam Marszałek, Torun.

Podstawa programowa kształcenia ogólnego (dla liceum ogólnoksztatcacego, liceum profilowanego i technikum), Rozporządzenie Ministra Edukacji Narodowej i Sportu z dn. 26 lutego 2002 r., Warszawa.

Rachwał T., 2004, Podstawy przedsiębiorczości. Słownik dla liceum ogólnoksztatcacego, liceum profilowanego i technikum. Wydawnictwo Nowa Era. Warszawa.

Suchodolski B., 1990, Wychowanie mimo wszystko, WSiP, Warszawa.

Śrutowska D., Rachwał T. (red.), 2005, Podstawy przedsiębiorczości. Multimedialny CD-ROM dla liceum ogólnokształcacego, liceum profilowanego i technikum. Wydawnictwo Nowa Era, Young Digital Poland, Warszawa-Gdańsk. 